\section{Kreft og nyresykdom}

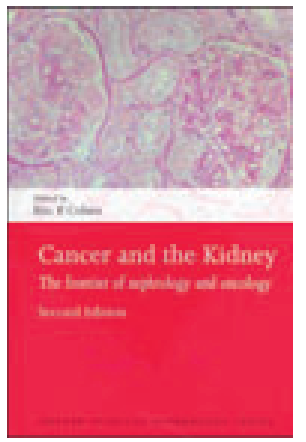

\section{Eric P. Cohen, red. \\ Cancer and the kidney}

The frontier of nephrology and oncology. 2. utg. 360 s, tab, ill. Oxford: Oxford University

Press, 2011. Pris GBP 48

ISBN 978-0-19-958019-4

Tittelen indikerer at boken er spesielt laget for nyreleger og onkologer, men etter min oppfatning er den like relevant for hematologer og til en viss grad urologer og kirurger. Forfatterne gir faktaopplysninger og råd for det kliniske arbeidet i problemstillinger som vi nesten hver dag møter på et større sykehus. Boken viser også tydelig de mange møtepunktene mellom ulike spesialiteter.

En kjedelig tittel bør ikke få deg fra å lese. Boken er godt skrevet, med innholdsliste som gjør det lett å slå opp og velge tema av interesse. Noe oppslagverk i vanlig forstand er den ikke, forfatterne går ikke nok i dybden, men surfer på overflaten med enkelte dypdykk i litt tilfeldige områder. Kvaliteten på kapitlene er gjennomgående rimelig bra, men ikke alltid imponerende.

Boken omhandler ikke bare kreftpasienten som utvikler nyrekomplikasjoner pga. behandling, enten det er med tradisjonell kjemoterapi, strålebehandling, nye biologiske substanser eller stamcelletransplantasjon. Forfatterne diskuterer også risikoen for nyreskade ved de ulike kreftformene og behandlingsstrategiene. De stiller spørsmål, men svarer ikke alltid på hvordan man best gjennomfører kreftbehandling hos pasienter med nedsatt nyrefunksjon. Et viktig tema er hvordan prognosen endres dersom kreftpasienten får akutt nyresvikt eller en kronisk nyreskade og blir dialysetrengende, eller kanskje forhindrer at pasienten får optimal behandling for sin kreftsykdom.

Akutt nyresvikt har fătt stor plass sammen med urinveisobstruksjon og nyrekomplikasjoner etter beinmargstransplantasjon. Hvordan skal man behandle akutte komplikasjoner som nyresvikt eller elektrolyttforstyrrelser hos kreftpasienter? Muligheten for paraneoplastiske glomerulopatier diskuterer vi daglig i vår avdeling, noe som også er tatt opp i boken. Paraproteinemi og assosiert nyreskade er ikke uvanlig og en utfordring både for hematologer og nyreleger. Det er en sammenheng mellom langvarig, kronisk nyresykdom/dialyse og risikoen for nyrekreft. Hvordan, og når, bør man utrede med tanke på kreftutvikling hos den kronisk nyresyke? Hva bør inkluderes i screeningprogram med henblikk på kreftutvikling hos nyretransplanterte?.

Alle de 13 kapitlene (med ulike forfattere, hovedsakelig amerikanske og britiske) starter med en kasuistikk relevant for problemstillinger eller temaer som man tar opp. Det øker leselysten. Referanselistene til hvert kapittel er omfattende. Det er få tabeller og figurer, men jeg oppfatter det ikke som en mangel. Det tjener redaktøren til ære at det er få gjentakelser, til tross for mange forfattere. Det er imidlertid en del slurvefeil som redaktøren burde ha luket bort, som feil på figurer og tabeller, og inkonsekvent bruk av enheter (SI og konvensjonelle enheter). Referansene er ikke alltid like relevante eller oppdaterte. Jeg har grundig gått gjennom noen kapitler som er av spesiell interesse for en nyrelege, og funnet at boken kanskje er noe overfladisk for den spesielt interesserte, men at den kan være et viktig supplement.

Jeg anbefaler boken for nyreleger og kolleger som behandler pasienter med maligne lidelser, for å få en bedre oversikt over kompliserte problemstillinger når nyresykdom og kreft opptrer samtidig.

Ingrid Os

Nyremedisinsk avdeling

Oslo universitetssykehus

\section{Nyttig om reproduksjonstoksikologi}

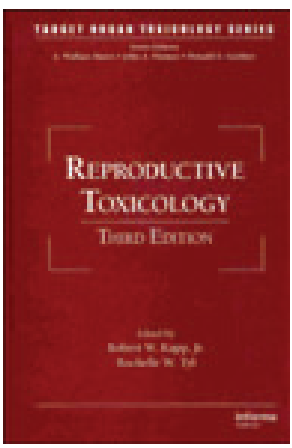

\author{
Robert W. Kapp Jr, Rochelle W. Tyl, red. \\ Reproductive toxicology
}

3. utg. 419 s, tab, ill. London: Informa Healthcare, 2010. Pris GBP 84

ISBN 978-142007343-0

Denne boken er en del av forlagets serie Target organ toxicology series. I 2010 forelå det to nye bøker, Toxicology of the skin og Toxicology of the nose and upper airways, sammen med nye og reviderte utgaver av Endocrine toxicology, Neurotoxicology og Reproductive toxicology. Bøkene er viktige fordi de tar utgangspunkt $i$ at en toksikologisk effekt i stor grad er spesifikt for et organ.

Reproduksjonstoksikologi har i de siste årene fått større oppmerksomhet, for eksempel var det omtrent dobbelt så mange publikasjoner i 2010 som i 2000. Dette skyldes først og fremst at man er blitt klar over at sykdommer relatert til reproduksjon er økende, og de er spesielt hyppige blant menn i den industrialiserte verden. Redusert spermkvalitet, kryptorkisme og hypospadi øker, i takt med økt forekomst av testikkelkreft. Det er store geografiske forskjeller, ved at Norge - sammen med Danmark - dessverre ligger helt i toppsjiktet, mens Finland og Sverige har langt mindre testikkelkreft og bedre spermkvalitet. Årsaken er ikke kjent, men kan være knyttet til eksponering i mors liv. Livsvaner og kjemikalier har tilsynelatende større betydning enn genetikk; finske innvandrere i Sverige blir mer lik svenskene i annen generasjon (i alle fall når det gjelder spermkvalitet). I dette perspektivet blir mekanismeforståelse og tidlig forebygging spesielt viktig. Det drives nokså lite reproduksjonstoksikologisk forskning i Norge. Aktiviteten er veldig mye større i Sverige og spesielt i Danmark. Bedre integrasjon av berørte fagmiljøer er svært ønskelig, og det er også behov for kompetanseheving.

Den nye utgaven av Reproductive toxicology er delt i fire: 1) Normal reproduksjon og utvikling (et selvsagt kunnskapsgrunnlag), 2) Regulatorisk evaluering av reproduksjon (sentralt $i$ arbeidet med å identifisere potensielle årsaksfaktorer som kjemikalier i mat, farmaka og forbrukerprodukter), 3) Utviklingstoksikologi i systemiske organsystemer (knytter reproduksjonstoksikologien opp mot endringer i andre organsystemer) og 4) Toksikologi i reproduksjonsprosessen (tar for seg kjønnsrelatert reproduksjonstoksikologi, stoffrelaterte virkninger og mekanismer).

Epigenetikk har fått spesielt stor oppmerksomhet i de senere årene, ved at DNA-metyleringsmønster ser ut til å kunne endres gjennom flere generasjoner som følge av kjemikalieeksponering. En slik mekanisme er muligens viktigst for det paternelle genomet som har en kort meiose sammenliknet med det maternelle. Det siste kapitlet tar for seg såkalte «omics», et nytt begrep på engelsk som er en samlebetegnelse på områder innen biologien som ender på -omics, for eksempel proteomics og genomics. En norsk betegnelse kunne være «omikk». Dette er potensielt viktige verktøy for å identifisere stoffer med effekter på reproduksjon og utviklingstoksikologi, i form av systematiske studier av endret mønster i genekspresjon og proteinuttrykk.

46 forfattere bidrar. Flere av dem er godt etablert i fagfeltet, mens andre må betegnes som mindre erfarne ved at de har en nokså kort vitenskapelig merittliste. Det som likevel slår meg mest, er at alle forfatterne er fra USA. Det er meget sterke europeiske så vel som australske fagmiljøer innen reproduksjonstoksikologi, og det er kanskje litt underlig at redaktørene kun har funnet bidragsytere fra ett land. Samtidig er det også skuffende at regulatoriske forhold 
bare gjelder USA, mens REACH, EUs omfattende system for evaluering og regulering av kjemikalier, avspises med tre linjer.

Teksten er tettskrevet, med overraskende lite bruk av illustrasjoner og ingen farger. Dermed får man mye informasjon for pengene, men den blir antakelig mindre tilgjengelig. Et godt stikkordregister er forresten svært viktig. En sjekk var ikke veldig oppløftende: «Testicular descent» viser til sidene $27-8$, mens «cryptorchidism» viser til 28, 306, 325. Det kan tyde på at stikkordlisten er laget automatisk og ikke er kontrollert av en fagperson.

Til tross for mindre innvendinger er boken viktig for å spre kunnskap om reproduksjon og reproduksjonstoksikologi. Kjøp den, og les den.

\section{Gunnar Brunborg}

Avdeling for kjemikalietoksikologi

Nasjonalt folkehelseinstitutt

\section{Gode operative løsninger - stort sett}
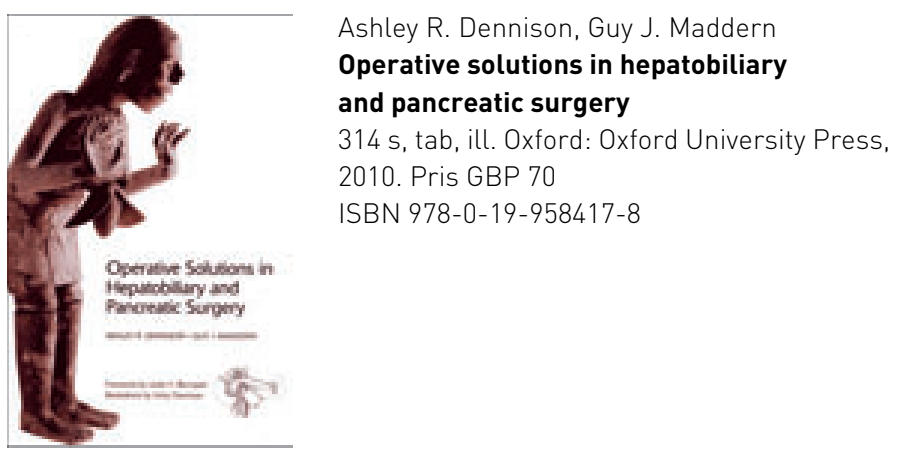

Ashley R. Dennison, Guy J. Maddern Operative solutions in hepatobiliary and pancreatic surgery

314 s, tab, ill. Oxford: Oxford University Press, 2010. Pris GBP 70

ISBN 978-0-19-958417-8

Forfatterne arbeider i henholdsvis England og Australia. Kompetanse innenfor lever-, galleveis- og pancreaskirurgien har de bl.a. fått gjennom arbeid og opplæring av legendariske Leslie H. Blumgart, som roser sine tidligere elever i et forord.

Dette er ingen ordinær lærebok i kortformat. Ikke et eneste røntgenbilde finnes, nesten ingen ting om sykdomsforekomst eller patologi er nevnt, og klinikk er bare helt kort beskrevet. Forfatterne setter søkelyset på behandlingsveivalg, inkludert operasjonstekniske problemer og løsninger.

Tematisk er det fem hovedkapitler: pancreas, duodenum, lever, galleblære og galleveier. En rekke problemstillinger, også noen relativt sjeldne, er belyst. Forfatternes vurderinger og løsninger synes velprøvde. Vi kjenner oss igjen i svært mange anbefalinger, selv om praksis hos oss i enkelte sammenhenger vil skille seg noe fra forfatternes. Deres foretrukne rekonstruksjon (separate tynntarmsløp for hepatikojejunostomien og pankreatikojejunostomien) etter Whipples operasjon (pankreatikoduodenektomi) for pancreaskreft er ikke vanlig i vårt miljø (figur 1.74, s. 82). Forfatterne er påfallende skeptiske til nytten av intervensjonsradiologisk embolisering ved blødende ulcus duodenum (s. 94), og deres indikasjon for kolecystektomi hos alle asymptomatiske pasienter $<65$ år med tilfeldig påviste galleblærekonkrementer (s. 211) er diskutabel.

Teksten er lettlest og supplert med flere nyttige tabeller og en rekke informative strektegninger. De illustrative strektegningene er faktisk ekte tegninger og ikke polerte dataillustrasjoner. Rent teknisk/kunstnerisk varierer de noe. Forfatterne har også laget en rekke algoritmer, der ulike utredningsløp og behandlingsveivalg blir skissert. Detaljene i disse algoritmene kan og bør diskuteres, og en slik diskusjon vil kunne avklare og kanskje bedre vår egen praksis.

Verdien ligger i forfatternes evne til å formidle nyttig, praktisk kunnskap. Dette er ikke kunnskapsbasert faktakunnskap, men snarere velprøvd, operativ klinisk praksis. Og jeg synes de gjør dette eminent, stort sett. Trykk og innbinding er solid, og trykkfeil er nærmest fraværende. Litteraturreferansene er gjennomgående relevante og oppdaterte. Et indeks på slutten er nyttig.
Jeg kan anbefale boken som et nyttig supplement. Den vil være aktuell både for spesialistkandidater og mer erfarne kirurger.

Jon Arne Søreide

Kirurgisk avdeling

Stavanger universitetssjukehus

\section{Detaljert håndbok i end okrinologi og diabetes}

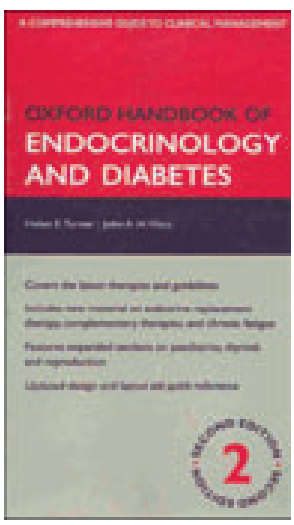

Helen E. Turner, John A.H. Wass Oxford handbook of endocrinology and diabetes

2. utg. 952 s, tab, ill. Oxford: Oxford University Press, 2009. Pris GBP 33

ISBN 978-0-19-856739-4

Dette er én av 51 håndbøker i serien Oxford handbook of ..., som er kjent for mange. Målgruppen er primært utdanningskandidater i endokrinologi, men også de av oss endokrinologer som ikke sliter med klisterhjerne.

Det er funnet rom for beskrivelse av svært sjeldne tilstander, f.eks. hypofysekarsinomer (60 tilfeller rapportert så langt, i verden). Videre er det positivt med et eget kapittel om endokrinologi og aldring. Jeg savner imidlertid mer om autoimmun diabetes hos voksne (Latent Autoimmune Diabetes mellitus in Adults, LADA). Behandling av subklinisk hypotyreose først ved TSH-verdier over 10 hos anti-TPO-positive pasienter er svært konservativt ut fra et skandinavisk ståsted, selv om litteraturen ikke er konklusiv. Når det gjelder veksthormonbehandling hos voksne, er imidlertid de norske kriteriene strengere. Kapitlet om laboratorieendokrinologi kunne vært utvidet til å omfatte forskjellige målemetoder som immunoassay, HPLC og GC/MS - da faget er svært laboratoriebasert. Interessante kulturforskjeller mellom Oxford i England og Norge ser vi når forfatterne anbefaler reduksjon av kveldsinsulin ved fysisk aktivitet «such as sex». I Norge fokuserer vi mer på spinning og jogging. I en avveining mellom teori og praksis synes jeg at boken kunne vært enda mer praktisk istedenfor å diskutere teoretisk uenighet.

Når jeg vurderer boken mot Internett-kilder som det kliniske oppslagsverket UpToDate, er svakheten at nye studier kommer til, for eksempel ACCORD-studien som viser at intensivert insulinbehandling øker mortaliteten hos pasienter med type 2-diabetes og samtidig hjerte- og karsykdom. For de som ønsker mer spesifikke lommehåndbøker, anbefaler jeg serien Oxford diabetes library.

Denne boken finnes også som App til 319 kroner. En annen App, EndocAlmanac, er bedre på illustrasjoner, men på ingen måte så utfyllende. Siden boken er beregnet på yngre leger kunne den i neste utgave kanskje bli enda bedre hvis en lege i utdanningsstilling blir medforfatter?

Tore Julsrud Berg

Endokrinologisk avdeling

Oslo universitetssykehus, Aker 